BIOKEMISTRI 16(2):102-105 (December 2004)

Printed in Nigeria
An international journal published by the

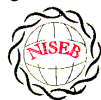

Oigerian Society for \&̊xperimental Siology

\title{
Effect of theobromine on serum total protein, albumin, iron and transferrin in albino rats
}

\author{
Eleojo B. MUSA ${ }^{1 *}$, Mbeh U. ETENG ${ }^{1}$, James OMALE ${ }^{2}$ and Joseph E. OLAJIDE ${ }^{3}$ \\ ${ }^{1}$ Department of Biochemistry, College of Medical Sciences, University of Calabar, Calabar, Nigeria. \\ ${ }^{2}$ Deparment of Biochemistry, Faculty of Basic Medical Sciences, University of Ibadan, Ibadan, Nigeria. \\ ${ }^{3}$ Department. of Biochemistry, University of Ilorin, Ilorin, Nigeria.
}

Received 18 February 2004

MS/No BKM/2004/004, () 2004 Nigerian Society for Experimental Biology. All rights reserved.

\begin{abstract}
The effect of theobromine, a cocoa alkaloid, on total serum protein, albumin, iron and transferrin were investigated in albino rats of wistar strain. Theobromine was administered intraperitoneally to three groups of rats B, C, and D, weighing between 200-250g averagely. Groups B, C and D respectively received $2.5 \mathrm{mg} / \mathrm{kg}$ body weight, $5.0 \mathrm{mg} / \mathrm{kg}$ body weight and $7.5 \mathrm{mg} / \mathrm{kg}$ body weight of theobromine repeatedly for 3 days and the control group A received physiological saline. Blood obtained from the sacrificed animal 24 hours later was collected in iron-free centrifuge tube, allowed to clot for an hour and serum separated by centrifugation. Results obtained showed that there was a statistically significant $(\mathrm{P}<0.05)$ dose dependent increase in mean serum iron in the test groups $\mathrm{B}, \mathrm{C}$ and $\mathrm{D}$. However serum transferrin levels showed a statistically significant $(\mathrm{P}<0.05)$ decrease in the test groups $\mathrm{B}, \mathrm{C}$ and $\mathrm{D}$ compared with control. Mean values of total serum protein in group $\mathrm{B}, \mathrm{C}$ and $\mathrm{D}$ showed no significant difference $(\mathrm{P}>0.05)$ when compared with the control. Also serum albumin showed no significant difference $(P>0.05)$ in the test groups from the control. Consequence of elevated serum iron and lowered transferrin levels are discussed in relation to iron transport and erythropoiesis.
\end{abstract}

Key words: Theobromine, iron binding, wistar rats, cocoa alkaloids

Present address: ${ }^{*, 2,3}$ Department of Biochemistry, Kogi State University, P.M.B 1008, Anyigba, Kogi State, Nigeria. *Author to whom all correspondence should be addressed at the present address. E-mail: elgbane@yahoo.com 


\section{INTRODUCTION}

The cocoa tree belongs to the genus theobroma, a group of small trees which grow in the Amazon basin and other tropical areas of south and Central Africa. Cocoa belongs to the family sterculiaceae of which only theobroma cocoa is cultivated widely of the over 20 species in the genus. Theobroma cocoa produces a group of compounds known as alkaloids. Typical alkaloids are derived from plant sources e.g cocoa, and are basic in chemical composition containing one or more nitrogen atoms, usually in a heterocyclic ring and have marked physiological action on man and other animals (Trease and Evans, 1978).

Alkaloids are extremely difficult to define because they do not represent a homogenous group of compounds either from the chemical, biochemical, or physiological view point (James et. al, 1977). Alkaloid were first isolated in the last century following the reintroduction into Medicine of a number of alkaloids containing drugs and were coincidental with the advent of the percolation process for drug extraction. Caffeine was the first alkaloid to be isolated among the methylxanthines in 1819 and was followed closely by theobromine and theophyline in 1821 (Trease and Evans, 1978). Theobromine (3, 7-dimethylxanthine), a white crystalline powder with a bitter taste, like caffeine $(1,3,7$ - trimethylxanthine $)$ and theophyline (1,3 - dimethylxanthine) is a purine alkaloid which is present in a number of plants particularly Theobroma cocao linn, other plants include kolanut and coffee.

Theobromine can also be produced synthetically. The alkaloid sublimes at about $260-290^{\circ \mathrm{C}}$ and may be purified by sublimation method when it forms colourless rhombic microcrystals. It is slightly soluble in cold water and in alcohol but becomes readily soluble when mixed with salt such as sodium salicylate, calcium salicylate and sodium acctate.

Previous works reported below have shown the toxic effect of cocoa mainly due to its alkaloid content. Manifestation of theobromine toxicity was first observed in poultry animals when undecorticated cocoa meal cake fed to chicken resulted in loss of weight, poor egg production and death presumably from theobromine poisoning (Terperton and Dudley
1943). Death in dogs receiving a proprietary food found later to include about $2 \mathrm{~g} / \mathrm{kg}$ of theobromine has been documented (Claugh, 1975).

Due to the fact that cocoa is usually processed into many food products such as chocolates and confectionery coating and as flavours in cakes, ice cream etc; it is the aim of this work to find out the effect of theobromine on total serum protein, albumin, iron and transferrin which could aid in discovering some of the biochemical effect of theobromine on the body.

\section{MATERIALS AND METHODS}

16 male white albino rats of Wistar strain weighing between 200-250g were obtained from the Biochemistry Department, College of Medical Sciences, University of Calabar, Calabar, Nigeria. The dried Cocoa beans used for this work were obtained from the Bakoko Market, Cross River State, Nigeria. The shells were removed by hand and the kernel powdered using mortar and pestle. This was sieved and stored in an airtight glass container until it was used for the extraction of the theobromine.

\section{Animal Grouping}

The rats were randomly allocated into four groups each containing four rats which were numbered and housed individually in wired screen bottom cases (Associated crates Ltd, stock port, England.) made of stainless steel and equipped to separate urine and faeces of the rats. The animals were kept at room temperature (25$37^{\circ} \mathrm{C}$ ) and reared on a commercial diet.

\section{Extraction and estimation of theobromine}

$10 \mathrm{~g}$ of cocoa powder was weighed into a $250 \mathrm{ml}$ bottle using a mettler Toledo PB 3002-5 digital balance. $100 \mathrm{ml}$ of chloroform, $10 \mathrm{ml}$ of $10 \% \mathrm{NH} 4 \mathrm{OH}$ were added into the bottle and shaken for 5 minutes using a Gallen Kamp flask shaker at $800 \mathrm{rpm}$ (Arnaud, 1978). $25 \mathrm{~g}$ of anhydrous $\mathrm{Na}_{2} \mathrm{SO}_{4}$ was later added and shaken for 30 minutes using the same flask shaker at $900 \mathrm{rpm}$ and the content was left over night after which it was filtered through a number 4 Whatman filter paper into a $250 \mathrm{ml}$ flask. The 
residue was thoroughly washed with $50 \mathrm{ml}$ of chloroform. The chloroform was distilled off using a water bath at $100^{\circ} \mathrm{C}$ (Arnaud, 1978).

\section{Theobromine administration}

Theobromine was administered intraperitoneally. Group A received a placebo (described above). Group B injected with $2.5 \mathrm{mg} / \mathrm{kg}$ body weight of theobromine. Group C with $5.0 \mathrm{mg} / \mathrm{kg}$ body weight and group D with $7.5 \mathrm{mg} / \mathrm{kg}$ body weight daily for 3 days. Food and water were provided ad libitum throughout the period.

\section{Collection of Blood Samples}

The animals were anaesthesized using chloroform 24 hours after the last administration and the blood samples collected by cardiac puncture into centrifuge tube using needle and syringe the blood was allowed to clot for an hour after which it was centrifuged at 10,000 rpm for 5 minutes using an MSE table-top centrifuge. Collection of samples was done between 8-10am since serum iron levels is affected by the time of the day among other parameters (Laurell, 1947).

\section{Determination of blood parameters}

Serum from each group was divided into four (4) portions for the estimation of total protein, albumin, Iron and transferrin. Total Serum protein determination was by the Biuret method (Gornall et al 1949) that gives purple colouration when peptide bonds react with cupric ions $\left(\mathrm{Cu}^{2+}\right)$ at alkaline $\mathrm{pH}$ which can be read at $540 \mathrm{~nm}$

Serum albumin was determined by modification of the Bromo cresol - green method of Mcpherson and Everald (1972). Albumin has the ability to bind certain dyes such as BCG. Bromocresol green (BCG) is a $\mathrm{pH}$ indicator which changes from yellow to blue in $\mathrm{pH}$ range $3.8-4.2$. There is a shift in the dyes peak absorption wave length which is proportional to the concentration of albumin present and which can be read at $632 \mathrm{~nm}$.

Serum Iron was determined by the method of International Committee for Standardization in Haematology (ICSH) (1978). The method employed the principle of dissociation of $\mathrm{Fe}^{3+-}$ from $\mathrm{Fe}^{3+}$ - transferrin complex and the reduction of the $\mathrm{Fe}^{3+}$ to $\mathrm{Fe}^{2+}$. Addition of coloured reagent result in formation of a deeply coloured ferrozine $\mathrm{Fe}^{2+}$ with an absorbance maximum at $562 \mathrm{~nm}$.

Transferrin determination was also by ICSH method. Transferrin is complexed with iron on treatment of the serum sample with excess iron. The iron in the complex is determined in the same manner as the Iron in serum and is a measure of the Total Iron Binding capacity, (TIBC).

\section{RESULTS}

The results in Table 1 indicate the mean value of serum protein in the test group B, C and D. There was no significant difference $(\mathrm{P}>0.05)$ with the values obtained in control. Mean values of Serum albumin in the test group B, C and D (Table 1) showed no significant difference $(\mathrm{P}>0.05)$ from the values of control.

Table 1: Mean values of Total serum Protein and Serum albumin $(\mathrm{g} / 100 \mathrm{ml})$

\begin{tabular}{|l|l|l|}
\hline Group of rats & $\begin{array}{l}\text { Total Serum } \\
\text { protein g/100ml }\end{array}$ & $\begin{array}{l}\text { Serum } \\
\text { albumin } \\
\mathrm{g} / 100 \mathrm{ml}\end{array}$ \\
\hline A (Control) & $6.40 \pm 0.84$ & $4.13 \pm 0.08$ \\
B & $6.43 \pm 0.35$ & $3.95 \pm 0.15$ \\
C & $6.25 \pm 0.50$ & $4.23 \pm 0.23$ \\
D & $5.15 \pm 1.20$ & $4.88 \pm 1.13$ \\
\hline
\end{tabular}

Table 2: Mean values of Serum Iron TIBC and Serum Transferrin $(\mathrm{mg} / \mathrm{kg}$ )

\begin{tabular}{|l|l|l|l|}
\hline Group of rats & Serum Iron $(\mathrm{mg} / \mathrm{kg})$ & TIBC Iron binding capacity $(\mathrm{mg} / \mathrm{kg})$ & Serum transferrin $(\mathrm{mg} / \mathrm{kg})$ \\
\hline A (control) & $4.64 \times 10^{-2} \pm 3.8 \times 10^{-5}$ & $17.25 \times 10^{-2} \pm 1.5 \times 10^{-4}$ & \\
B & $6.43 \times 10^{-2} \pm 1.0 \times 10^{-4}$ & $13.93 \times 10^{-2} \pm 1.4 \times 10^{-4}$ & $11.85 \times 10^{-2} \pm 7.3 \times 10^{-5}$ \\
C & $6.97 \times 10^{-2} \pm 3.5 \times 10^{-5}$ & $13.21 \times 10^{-2} \pm 4.4 \times 10^{-4}$ & $9.61 \times 10-2 \pm 6.7 \times 10^{-5}$ \\
D & $7.32 \times 10^{-2} \pm 3.5 \times 10^{-5}$ & $11.79 \times 10^{-2} \pm 3.4 \times 10^{-4}$ & $9.11 \times 10^{-2} \pm 5.0 \times 10^{-4}$ \\
\hline
\end{tabular}


The mean values obtained for serum Iron (Table 2). For the test groups are higher than, and showed statistical significant difference $(\mathrm{P}<0.05)$ compared with the control.

Serum transferrin (Table 2) showed lower mean values and significant difference $(\mathrm{P}<0.05)$ compared with control values. The mean values of TIBC for the test groups $\mathrm{B}, \mathrm{C}$ and D (Table 2) compared with the control showed similar trend and statistical difference with serum transferrin.

\section{DISCUSSION}

From the result in table 1, the statistical insignificant difference in the mean values of total serum protein and serum albumin when compared with the mean values for the control group may be that the levels of theobromine concentration injected into the rats have no biochemical effect on the levels of these parameters in the rats. As shown by the result, theobromine induces a significant increase in serum levels of Iron in rats and the effect was found to be dose dependent.

However, since almost all of the Iron in Serum is bound to transferrin in the form of $\mathrm{Fe}$ ${ }^{3+-}$ protein complex (Gyton 1986) it is expected that with the raised serum Iron, the level of transferrin should also be elevated but evidence obtained in this work is to the contrary with a statistically significant decrease in both total iron binding capacity (TIBC) and transferrin. The observed elevated level of serum Iron may be due to the binding of theobromine onto transferrin which could probably inhibit or block the receptor site for Iron thus Iron is not bound leading to elevation of serum iron.

\section{Conclusion}

Many workers have reported on the toxic effect of theobromine in various animal species. However the effect of theobromine consumed in diets on parameters studied in this work (serum iron total serum protein, transferrin and albumin) has not been reported.

The effect of theobromine on iron level in the rats as reflected by the serum iron level suggests that the consumption of theobomine be discouraged. However since crude extracts were employed in this investigation, the use of pure theobromine is suggested for further research.

\section{REFERENCES}

Arnaud, M.J. (1978) Metabolic Pathway of Theobromine in rats. J. Biol. Chem. 228:315323

Claugh G.W. (1975) Alkaloids in Plant. Vert J. 11:98-196

Gornal, A.U., Barde Will, L.J. and David M.M. (1949) Determination of Serum Proteins by means of Biuret reaction. J. Biol. Chem. 177:751.

Gyton A.C and Gannon M.D. (1986) Plasma Protein: Textbook of medical physiology. $7^{\text {th }}$ ed W.B Sauders Co. Philadephia Toronto. Pp 4647.

ICSH (1978) The measurement of total and unsaturated iron binding capacity, in serum. $\mathrm{Br}$. J. Hematol. 35: 281-290.

James, E.R. (1977) Pharmacognosis, James E.R. (ed) $7^{\text {th }}$ (ed) Varrotyler Co. London. Pp 227-230, 292-297.

Laurell, C.B. (1947) Studies on the transportation and metabolism of iron in the body. Acta physiol. Scand.14: 1-29.

Mcpherson I.G. and Everald D.W. (1972) Serum Albumin estimation: Modification of the bromocresol green method. Clin. Chem. Acta 37: 117-121.

Terperton H. and Dudley, F.J. (1943) Toxicity of alkaloids. Poultry J. 2:28-29.

Trease and Evans (1978) Pharmacognosis. (Trease and Evans ed) $11^{\text {th }}$ ed. Varro tyler Co. London. Pp 526-695. 